\title{
Discussion of Teaching Reform of E-Commerce English
}

\author{
Yilei Pei* \\ Department of Information Management and E- \\ Commerce, Management College \\ Beijing Union University \\ Beijing, China \\ peiyilei@126.com \\ *Corresponding author
}

\author{
Bing Yang \\ Management College \\ Beijing Union University \\ Beijing, China \\ yangbing@buu.edu.cn
}

\begin{abstract}
The course of E-Commerce English meets the needs of cultivating compound talents of the new century, and helps students consolidate E-Commerce knowledge learned during the undergraduate period, in order to adjust the requirements of the future work. This paper points out the existing problems in ECommerce English teaching, and puts forward the way of improving teaching quality of E-Commerce English from the perspectives of changing the teaching idea, integrating theory teaching and practice teaching, optimizing teaching content, reforming teaching methods and improving learning assessment program.
\end{abstract}

Keywords-e-commerce english; teaching refor; teaching quality; improvement

\section{INTRODUCTION}

With the wide application of Internet and information technology, E-Commerce develops rapidly. E-Commerce profession is set up in more than 700 universities. "Ecommerce English" is crucial for students majoring in Ecommerce as a basic course in E-Commerce profession. As the subsequent course of college English, the teaching purpose of E-commerce English is mainly to foster students' certain ability to read and translate science and technology literature, to write scientific paper and to have the science and technology communication of E-Commerce profession using oral English, which enables students to read some English literature, and promote understanding of discipline hotspots, foreign academia and industry dynamics. E-Commerce profession involves management, economics, computer science, network technology, law and other fundamental courses, and covers a wide range of knowledge. The broad knowledge system and the rapid development of knowledge updating make ECommerce English teaching difficult.

Management College of Beijing Union University began to recruit students of E-Commerce profession in 2001, so ECommerce English teaching is still at the initial stage, and there are some problems which influence the teaching effect. Therefore, we need to change the thinking, realize the necessity of reforms and conduct the fundamental reform for teaching thought, teaching mode, teaching means and teaching methods of E-Commerce English, in order to adapt to the challenge of cultivating compound talents in application-oriented universities.

\section{PROBLEMS OF TEACHING AND LEARNING IN E- COMMERCE ENGLISH}

\section{A. Neglecting E-Commerce English for long}

E-Commerce English has special position. The learning of E-Commerce English is different from that of general public English. Students don't have the pressure from passing CET-4 and CET-6. The learning of E-Commerce English is also different from that of professional courses from which students can learn some professional skills. Therefore, many students think it's useless to learn E-Commerce English and do not attach importance to it naturally.

\section{B. There Being Big Differences in Students' English Levels without High Learning Interest}

In the process of learning E-Commerce English, there are more professional vocabularies, more complex sentence structures, and extensive contents involving Internet technology, network marketing, electronic payment system, logistics management, E-Commerce law, E-Commerce security, reading and writing foundation in business, which leads to the differences of students' interest in learning and the ability to accept. Some students are able to understand teaching contents better, while it is laborious for other students to understand professional vocabularies. In addition, there are big differences in students' English levels, which make students have higher learning enthusiasm at first, but after a period of time feel it difficult, and gradually lose confidence. Then they are not active in class, without high interest in learning and poor initiative and there is no active classroom atmosphere. Therefore, learning effect is poor, which leads students to give up learning the course finally.

\section{The Single Teaching Form of E-Commerce English}

The traditional teaching form of E-Commerce English centers on text teaching. The teaching form teachers use in class is "reading words, texts and translation". In the whole process of teaching, students hardly participate, while teachers say continually. Students' enthusiasm is not mobilized, and teaching effect is poor. In the process of teaching, practicability of E-Commerce English is not emphasized, which makes ECommerce English unable to reflect the special use property, so that some students think "they learned nothing" or "what they learned is useless" after learning this. 


\section{The Single Assessment Method of E-Commerce English}

The traditional test form of E-Commerce English assessment is the translation of professional literature. The assessment method is single with the narrow coverage, and not conducive to the evaluation of students.

\section{THE WAYS TO IMPROVE TEACHING QUALITY OF E- COMMERCE ENGLISH}

The teaching and learning of E-Commerce English is not only different from that of public English, but also different from that of professional courses. On the one hand, teachers should adjust teaching methods according to the particularity of the teaching and learning; on the other hand, teachers should constantly enrich the content, improve teaching methods, and enhance teaching quality according to the teaching aim. Teachers should do the following points:

\section{A. Changing Teaching Philosophy and Teacher's Role, and Diversifying Teaching Forms}

Teachers should make students pay more attention to the learning of E-Commerce English. Before teaching, teachers should explain the importance of the teaching and learning of E-Commerce English, combining with the needs of social development. In the process of the teaching and learning of ECommerce English, teacher s' leading status is without doubt, which can't substitute for students' autonomous learning process, so teachers must break the traditional teaching method in E-Commerce English class that is mainly based on teachers with students' listening and cramming. It is necessary to understand teachers' leading status of classroom teaching correctly and explore the teaching way and method of the most suitable for students' characteristics and needs actively. Modern college students have the relatively active characteristic, and are difficult to accept the boring teaching ways. So teachers can use the flexible and various teaching ways such as heuristic teaching, interactive teaching, taskguiding teaching, group discussion and dialogue. Teachers should combine various teaching forms, taking teaching as the forerunner, basing on learning and accumulating, strengthening knowledge by participation and consolidating by practical application, aiming at improving the ability of using ECommerce English, centering on students, according to students' actual needs, inspire and encourage students to participate in the teaching process actively, in order to enable every student to set a reasonable and practical personal learning objective, combined with teaching goals of E-Commerce English, according to their English foundations. At the same time, in the teaching design, teachers should pay attention to guiding, inspiring and demonstrating to help students participate in the learning process, and create conditions for students' oral communication around the content of the text to enhance students' learning interests, and learn pleasantly in the good atmosphere that teachers and students create together.

\section{B. Integrating Theory Teaching and Practice Teaching, Strengthening Practical Exercises and Cultivating Practical Ability}

Teachers should focus on the integration of English teaching and practice teaching, make full use of existing teaching practice, increase students' opportunities of practicing using E-Commerce English, enhance students' ability to use English comprehensively, and strive to make the teaching of this course achieve optimal effect. E-Commerce is a new commercial pattern based on the Internet, and should be learned from the developed countries in many ways. The leader of E-Commerce Jack Ma thought E-Commerce talents should have three capabilities, namely English, computer and business. For example, after leading students to visit E-Commerce sites abroad, teachers can let students click on and buy their favorite commodities first, which make students be familiar with the differences between domestic and foreign shopping websites, and also learn foreign E-Commerce laws and regulations on related English website, and then let students tell the teacher problems and difficulties they met by E-mail, at last let students try designing their own shop website by English mode, in order to achieve the effect of synchronous learning of the theory and practice. At the same time, teachers can encourage students to use E-Commerce English, combing the actual requirements of academic papers, graduation design and employment and other teaching practice links. When students write academic papers, they need translating an English paper designated by the teacher into Chinese, and sorting out the paper in accordance with the format of scientific literature. In the process of graduation design, students must collect a certain quantity of English literature, in order to pinpoint the development history and current situation abroad of the research project, complete English literature review related to papers through data collection and sorting, also translate English title, and write English abstract and keywords according to the content of their own paper. In the process of employment, in order to raise the employment threshold and broaden employment channels, students need writing a resume in English, also collecting relevant industry and product introduction in English so as to participate in the professional interview, and pinpointing the English expression of terminology within the industry.

\section{Optimizing the Teaching Content to Enable Students to Learn to Meet Practical Needs}

Due to the constraint on teaching time and students' English level, the content teachers taught shouldn't be comprehensive, but be focused with the goal, and special and refined. Teachers should set learning objectives for each part of learning content, select the key learning content around learning objectives for students to master. Teachers should divide the teaching goal into several small tasks, and achieve the task one by one; and put the key points of the knowledge into the text teaching, with specific examples, to make students gradually master the learning characteristics of E-Commerce English. In the text learning, teachers should choose to do several demonstrations of translation, and let students try reading the rest parts by themselves. For students' problems in the reading, teachers should summarize, analyze and explain further, in order to understand students' mastery of the actual knowledge. In the introduction of professional courses, teachers may add to the development of celebrities and famous companies in ECommerce industry to enlarge students' knowledge. In the teaching of each lesson, teachers should try to design a lot of scenarios and various business simulations, assign five or six students to make one-minute speech in class, encourage students to conduct the training of listening and speaking with the praise and encouragement. Teachers should let students 
learn each lesson relaxingly, happily, and interestingly; and let students learn each point of knowledge to accumulate and to learn to meet practical needs.

\section{Reforming Teaching Methods to Improve Students' Learning Initiative}

Use task-driven teaching method. First of all, teachers can divide students into study team, 4 persons each group, and select a person as the headman. Secondly, teachers can divide the content which is to be taught into a number of tasks, and give each team a task. Students in each team preview the task according to the assignment, and explain the task they are assigned to in class. There is the competition carried out among teams. Then teachers conduct the supplement. Finally, teachers mark according to the completion of each team. Through this teaching method, everyone has the task and the goal is clear. So, there isn't the situation that students don't participate in classroom teaching in class, on the contrary, students' enthusiasm is greatly enhanced and classroom atmosphere becomes active.

Use teaching methods of combining multimedia teaching and network teaching. E-Commerce English itself is a relatively dull course. Therefore, teachers can make full use of modern education technologies and methods in the teaching process, teach students in the multimedia classroom, and demonstrate teaching content using multimedia information all round. The multimedia courseware can provide abundant information and enrich the teaching content of E-Commerce English; multimedia courseware integrates many kinds of materials (video, audio, animation, text, etc.) and is able to make teaching difficulties become vivid. Using multimedia courseware in teaching flexibly can enrich the teaching content, and stimulate students' interests in learning. At the same time, teachers can open the e-learning classroom, which provides the convenient communication between teachers and students, promote students' autonomous learning, broaden the knowledge of the course, and improve teaching effect. Students conduct asynchronous learning through browsing the e-learning classroom of the course (http://elearning.buu.edu.cn/ main.html) according to the condition, the target and the method the teacher proposed after class. The e-learning classroom can demonstrate structuralized knowledge related to the learning topic and extensible learning resources; and also provide the space of online consultation and discussion and Q \& A guide. Students can download the teaching resources for autonomous learning and the e-learning classroom expands the space of the knowledge.

\section{E. Improving Learning Assessment Plan and Paying Attention to Students' Daily Assessment}

Curriculum assessment system assessment is an effective way to check the teaching effect and urge students to learn. In order to improve students' English level and meet the needs of the society, the curriculum assessment system should be effective and reasonable. Therefore, in the formulation of assessment plan, teachers should increase the proportion of the usual performance, and combine the usual performance and the final performance. Performance assessment of E-Commerce English of Management College is composed of two parts: the usual performance and the final performance, half and half. Daily assessment includes attendance (10\%), classroom lecture $(10 \%)$, quizzes $(10 \%)$, the recitation of classic paragraphs $(10 \%)$, and practice (10\%). Final assessment is mainly in the form of written examination, and according to students' actual situation it may be open-book or closed-book. If students' English foundation is weak, the teacher can use closed-book form, including fundamental knowledge (10\%), translation $(20 \%)$, essay writing (10\%), and noun explanation (10\%), and the examination time is 90 minutes. If students' English foundation is better, teachers can use open-book form, and combine the open-book written examination and the paper, half and half. The theme of the paper should combine employment direction and postgraduate profession, which is arranged in the middle of the term, Students can choose the direction according to their own actual situation, collect data, and submit a onethousand-word professional English literature at the end of the term. Open-book written examination is aimed at mastering professional vocabularies, translating scientific papers and writing abstracts. Using the dictionary and other auxiliary tools in examination is allowed, and the examination time is 90 minutes. By taking reasonable assessment methods, teachers can mobilize students' enthusiasm fully and improve teaching effect.

\section{CONCLUSIONS}

At present, E-Commerce is booming. As international language, E-commerce English is showing its importance increasingly. Therefore, the course of E-Commerce English for E-Commerce students meets the needs of cultivating compound talents of the new century, and helps students consolidate ECommerce knowledge learned during the undergraduate period, in order to adjust the requirements of the future work. In the teaching and learning of E-Commerce English, teachers should improve teaching effect of E-Commerce English by organizing the classroom form clever, taking flexible teaching methods, and making full use of modern teaching resources, and lay a good foundation for mastering and using E-Commerce English correctly and skillfully to carry out business activities. Teachers should follow the principle of taking students as the center, use different teaching methods, to improve students' learning motivation, stimulate students' curiosity, and accomplish the teaching and learning of the course better, according to students' different levels, on this basis.

\section{ACKNOWLEDGMENT}

The research is supported by Project of Higher Vocational Education and Teaching Reform (No. 1104581114) and Project of the Improvement of Teaching Quality in Beijing Union University.

\section{REFERENCES}

[1] Yaolei Hu. "Discussion on business English teaching," Agriculture Network Information, vol. 5, pp. 132-134, 2012.

[2] Tingting Li. "How to make the English teaching more practical," Learning Weekly, vol. 2, pp. 159-160, 2013.

[3] Xiaoe Peng, Zhe Zhou. "On the cooperative learning model in business English classroom teaching," Journal of Hunan University of Commerce, vol. 19, pp. 124-128, 2012. 